\title{
Detection of Cucurbit Yellow Stunting Disorder Virus Infecting Watermelon in South Carolina
}

\author{
Chandrasekar S. Kousik ${ }^{1,+}$ and Scott Adkins ${ }^{2}$ \\ ${ }^{1}$ USDA-ARS, U.S. Vegetable Laboratory, Charleston, SC 29414 \\ ${ }^{2}$ USDA-ARS, U.S. Horticultural Research Laboratory, Fort Pierce, FL 34945
}

Accepted for publication 27 March 2020.

Keywords: cucurbit yellow stunting disorder virus, CYSDV, Citrullus lanatus, cucurbits

Watermelon (Citrullus lanatus) is an important cucurbit crop grown in 44 states in the United States of America (USA). South Carolina (SC) had the seventh largest watermelon production area in USA with 4,500 acres in 2018 valued at approximately $\$ 17$ million (https://www.nass.usda.gov/Surveys/Guide_to_NASS_Surveys/ Vegetables/index.php). In the past few years, whitefly-transmitted viruses including cucurbit yellow stunting disorder virus (CYSDV), squash vein yellowing virus (SqVYV), and cucurbit leaf crumple virus $(\mathrm{CuLCrV})$ have become an economic problem in watermelon production in Georgia (GA) and Florida (FL) in the southeastern USA (Adkins et al. 2011; Gadhave et al. 2018; Kousik et al. 2012; Polston et al. 2008; Turechek et al. 2010). In late 2017, CuLCrV was identified in SC for the first time (Keinath et al. 2018).

In June 2019, four watermelon plants displaying symptoms of virus infection including stunting, leaf crumpling, interveinal chlorosis, and necrosis of leaf margins (Fig. 1) were observed in a research field at the U.S. Vegetable Laboratory farm in Charleston, SC. Whiteflies were also observed on the abaxial surface of the leaves. One plant was tested for the presence of CuLCrV, CYSDV, SqVYV, and aphid-transmitted papaya ringspot virus (PRSV) by reverse transcription polymerase chain reaction (RT-PCR) using previously described primers (Keinath et al. 2018; Rubio et al. 2001; Turechek et al. 2010). Amplicons of the expected size were only observed for $\mathrm{CuLCrV}(\sim 1 \mathrm{~kb})$ and CYSDV $(\sim 0.7 \mathrm{~kb})$. $\mathrm{CuLCrV}$ despite having a DNA genome was detected using RTPCR from its mRNA present during replication in the plants sampled (Adkins et al. 2009; Keinath et al. 2018). Because CYSDV was not previously reported from SC, we continued to monitor the field regularly for virus symptoms during the summer season. In mid-August 2019, 15 additional plants (1.9\% incidence) were observed with similar symptoms of virus infection. Total RNA was extracted from all 15 samples using a Direct-zol RNA isolation kit (Zymo Research, Irvine, CA) per the manufacturer's instructions and tested for CYSDV, SqVYV, and PRSV by RT-PCR as

${ }^{\dagger}$ Corresponding author: C. S. Kousik; Shaker.Kousik@ars.usda.gov

Funding: This work was funded by National Institute of Food and Agriculture (USDA-NIFA-SCRI-2018-51181-28420)

The author(s) declare no conflict of interest.

This article is in the public domain and not copyrightable. It may be freely reprinted with customary crediting of the source. The American Phytopathological Society, 2020 described above. Total DNA was extracted using a DNeasy Plant Mini kit (Qiagen, Germantown, MD) and tested for CuLCrV by PCR as described above. Amplicons of the expected size were again observed for CYSDV $(\sim 0.7 \mathrm{~kb})$ and $\mathrm{CuLCrV}(\sim 1 \mathrm{~kb})$ from all samples. No amplicons were obtained for SqVYV or PRSV. To confirm the presence of CYSDV, a second set of primers specific for the Hsp70h gene (Kuo et al. 2007) was also used for RT-PCR. Amplicons of the expected size $(\sim 0.15 \mathrm{~kb})$ were observed from all 15 samples. All three amplicons (two CYSDV and one CuLCrV) were cloned from six representative samples, sequenced, and analyzed. Amplicon sequences from three samples were deposited in GenBank.

Partial CYSDV coat protein (CP) sequences for these samples (GenBank accession nos. MN807937 to MN807939) were 100\% identical to each other and to CYSDV isolates from GA, FL, Arizona, and California (GenBank accession nos. MF960766, EU596528, FJ492808, and AF312799, respectively). Similarly, partial CYSDV Hsp70h gene sequences for these samples (GenBank accession nos. MN807940 to MN807942) were 100\% identical to each other and were 97 to $100 \%$ identical to CYSDV isolates from Arizona, California, Lebanon, and Spain (GenBank accession nos. FJ492808, EU596530, KC633820, and AY242078, respectively). Partial CuLCrV DNA A sequences (GenBank accession nos. MN807943 to MN807945) for these samples were 99 to $100 \%$ identical to each other and were $99 \%$ identical to prior SC $\mathrm{CuLCrV}$ sequences (GenBank accession nos. MG920141 and MH013228). Both virus identification methods (CP and Hsp70h) confirmed that CYSDV was indeed present in watermelon samples in SC.

The geographic range of CYSDV and other whitefly-transmitted viruses continues to expand into and within major cucurbitproducing regions with each production season, especially in the southeastern USA. It is now well documented that CYSDV is transmitted by whiteflies in other parts of USA and the world (Adkins et al. 2011; Gadhave et. al. 2018; Gil-Salas et al. 2011; Turechek et al. 2010). This is the first report of CYSDV infecting watermelon or any other plant in SC, although the virus has been described from other states in USA including FL and GA in the southeast and Arizona and California in the west. These three whitefly-transmitted viruses of cucurbits (CYSDV, CuLCrV, and SqVYV) are now present in the three major southeastern cucurbitproducing states (SC, GA, and FL). Mixed infections of CYSDV and $\mathrm{CuLCrV}$ have previously been detected in cucurbits in GA, FL, and California (Adkins et al. 2009, 2011; Gadhave et al. 2018; Kuo 


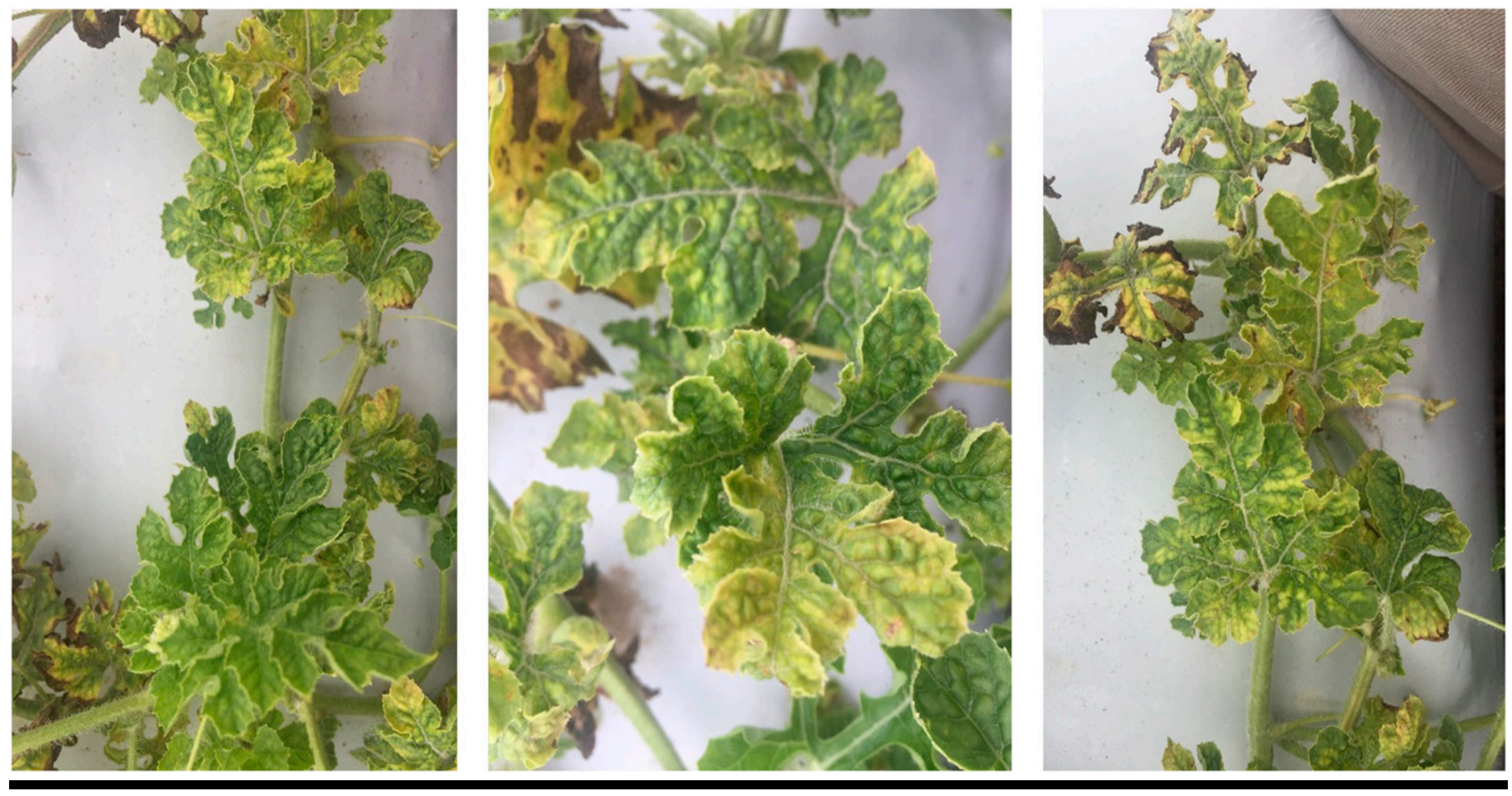

FIGURE 1

Symptoms of mixed virus infection on watermelon samples collected from plants in a field in South Carolina. Cucurbit yellow stunting disorder virus and cucurbit leaf crumple virus were detected in these samples by RT-PCR as described in the text. Symptoms of virus infection include stunting, leaf crumpling, interveinal chlorosis, and necrosis of leaf margins.

et al. 2007; Polston et al. 2008), similar to our SC results. These three whitefly-transmitted viruses now need to be considered in management plans by SC growers and extension agents. Knowledge of the presence of CYSDV, an additional virus, infecting cucurbits in SC is also important from a regulatory perspective. Additional studies will be required to determine the extent of the presence of CYSDV in SC. Preventive management of the whitefly vector in greenhouses during transplant production and subsequently in the field may also become necessary.

\section{Literature Cited}

Adkins, S., Webster, C. G., Baker, C. A., Weaver, R., Rosskopf, E. N., and Turechek, W. W. 2009. Detection of three whitefly-transmitted viruses infecting the cucurbit weed, Cucumis melo var. dudaim, in Florida. Plant Health Prog. 10. doi: 10.1094/PHP-2009-1118-01-BR.

Adkins, S., Webster, C. G., Kousik, C. S., Webb, S. E., Roberts, P. D., Stansly, P. A., and Turechek, W. W. 2011. Ecology and management of whitefly-transmitted viruses of vegetable crops in Florida. Virus Res. 159:110-114.

Gadhave, K. R., Dutta, B., Coolong, T., Sparks, A. N., Adkins, S., and Srinivasan, R. 2018. First report of cucurbit yellow stunting disorder virus in cucurbits in Georgia, United States. Plant Health Prog. 19:9-10.
Gil-Salas, F. M., Peters, J., Boonham, N., Cuadrado, I. M., and Janssen, D. 2011. Yellowing disease in zucchini squash produced by mixed infections of cucurbit yellow stunting disorder virus and cucumber vein yellowing virus. Phytopathology 101:1365-1372.

Keinath, A. P., Ling, K. S., Adkins, S., Hasegawa, D. K., Simmons, A. M., Hoak, S., Mellinger, H. C., and Kousik, C. S. 2018. First report of cucurbit leaf crumple virus infecting three cucurbit crops in South Carolina. Plant Health Prog. 19:322-323.

Kousik, C. S., Adkins, S., Turechek, W. W., Webster, C. G., Webb, S. E., Baker, C. A., Stansly, P. A., and Roberts, P. D. 2012. Progress and challenges in managing watermelon vine decline caused by whitefly transmitted squash vein yellowing virus (SqVYV). Isr. J. Plant Sci. 60:435-445.

Kuo, Y.-W., Rojas, M. R., Gilbertson, R. L., and Wintermantel, W. M. 2007. First report of cucurbit yellow stunting disorder virus in California and Arizona, in association with cucurbit leaf crumple virus and squash leaf curl virus. Plant Dis. 91:330.

Polston, J. E., Hladky, L. L., Akad, F., and Wintermantel, W. M. 2008. First report of cucurbit yellow stunting disorder virus in cucurbits in Florida. Plant Dis. 92:1251.

Rubio, L., Abou-Jawdah, Y., Lin, H.-X., and Falk, B. W. 2001. Geographically distant isolates of the crinivirus cucurbit yellow stunting disorder virus show very low genetic diversity in the coat protein gene. J. Gen. Virol. 82:929-933.

Turechek, W. W., Kousik, C. S., and Adkins, S. 2010. Distribution of four viruses in single and mixed infections within infected watermelon plants in Florida. Phytopathology 100:1194-1203. 